DOI: 10.15740/HAS/IJAS/14.2/367-370

\title{
Resource use efficiency and resource use pattern of soybean in Dharwad district of Karnataka: An economic analysis
}

\author{
Priyadarshini C. Gadad*, Shilpa P. Chowti and S.M. Mundinamani \\ Department of Agricultural Economics, College of Agriculture, University of Agricultural Sciences, Dharwad \\ (Karnataka) India \\ (Email : chintipriya@gmail.com)
}

\begin{abstract}
The study was conducted to know the resource use efficiency and resource use pattern in Soybean cultivation in Dharwad district of Karnataka. In Dharwad district 2 villages were selected randomly such as, Kavalageri and Narendra. From each village, 15 respondents growing Soybean were selected thus making a total sample of 30. Multistage sampling procedure was followed for selection of 30 Soybean growing farmers. Production function techniques were used to analyze the data. To estimate the resources use efficiency Cobb-Douglas production function was employed and Allocative efficiency = MVP/MFC. In order to determine the efficiency of allocation of the resources or price efficiency. The analysis of input utilization clearly indicates that the labour utilization was more. With respect yield obtained in study area was 21.24 quintal of main product and 15.07 tones of by product. The regression co-efficient of fertilizer (0.27) and bullock labour (0.05) are significant hence, it indicating increase in the use of these resources over and above the present level lead to a significant increase in gross returns. Whereas, the resources in study area was over utilized but are still in the rational region of production except hence there is need of optimal use of resources.
\end{abstract}

Key Words : Soybean, Protein, Animal feed, Crop

View Point Article : Gadad, Priyadarshini C., Chowti, Shilpa P. and Mundinamani, S.M. (2018). Resource use efficiency and resource use pattern of soybean in Dharwad district of Karnataka: An economic analysis. Internat. J. agric. Sci., 14 (2) : 367-370, DOI:10.15740/HAS/ IJAS/14.2/367-370. Copyright@2018: Hind Agri-Horticultural Society.

Article History : Received : 27.12.2017; Revised : 28.04.2018; Accepted : 14.05.2018

\footnotetext{
* Author for correspondence:
} 